\title{
INDIVIDUALNA VIŠEJEZIČNOST U KONTEKSTU HRVATSKOGA OBRAZOVNOG SUSTAVA
}

\author{
Marina Jajić Novogradec \\ Sveučilište u Zagrebu \\ Filozofski fakultet u Zagrebu
}

\section{Sažetak}

Individualna višejezičnost definira se prvenstveno s obzirom na raslojenost verbalnoga repertoara pojedinca (Banjavčić, Erdeljac, 2009, 18). Tako Königs (2000 u Neuner, 2004, 15) razlikuje tri vrste individualne višejezičnosti: retrospektivnu višejezičnost (engl. retrospective plurilingualism), koja se odnosi na dvojezične govornike koji dolaskom na nastavu već posjeduju znanje u drugome jeziku (J2 znanje), odnosno znanje jezika koji je i predmet nastave i prema tome su u prednosti naspram ostalih učenika; retrospektivno-prospektivnu višejezičnost (engl. retrospective - prospective plurilingualism), koja podrazumijeva višejezične govornike koji su dolaskom na nastavu u prednosti naspram ostalih učenika $\mathrm{u}$ inojezičnome znanju, no niti jedan od njihovih jezika nije predmet nastave, već daljnjim učenjem trećega ili dodatnoga jezika razvijaju svoju višejezičnost, i prospektivnu višejezičnost (engl. prospective plurilingualism), specifičnu za učenike koji su dolaskom na nastavu jednojezični govornici i svoju višejezičnost razvijaju učenjem ponajprije prvoga stranog jezika $\mathrm{u}$ školi. Posljednja vrsta višejezičnosti, odnosno prospektivna višejezičnost, karakteristična je za većinu europskih škola, a tako i Hrvatsku, gdje se polaskom u školu većina učenika po prvi puta susreće s učenjem jednoga ili više stranih jezika te svoju višejezičnost razvijaju učenjem ponajprije prvoga stranog jezika u školi. 
Nova perspektiva obrazovanja glede učenja stranih jezika u Hrvatskoj započinje uvođenjem barem jednoga stranog jezika kao obaveznoga nastavnog predmeta u osnovne škole 2003. godine, a u ostalim ciklusima obrazovanja i drugih stranih jezika. Prema ZEROJ-u (Zajedničkom europskom referentnom okviru za jezike, 2005, 4) višejezični pristup podrazumijeva stvaranje zajedničke komunikacijske kompetencije svih jezika koje učenik poznaje i kojoj pridonose znanje i iskustvo svih njegovih jezika, a u kojoj se svi jezici međusobno isprepliću. To svakako uključuje povezivanje materinskoga jezika, prvoga stranog jezika i ostalih dodatnih jezika koje učenik uči, bilo konsekutivnim slijedom ili paralelno.

Stoga se i cilj jezičnoga obrazovanja mijenja i ne obuhvaća više ovladavanje jednim ili dvama, čak i trima jezicima zasebno, što dovodi k težnji idealnoga izvornog govornika, već stvaranje jezičnoga repertoara $\mathrm{u}$ kojem sve jezične sposobnosti dolaze do izražaja. U takvome slučaju ponuda stranih jezika u obrazovnim ustanovama mora biti raznolika, a učenicima se mora pružiti mogućnost razvijanja višejezične kompetencije. Cilj ovoga rada je dati teorijski prikaz individualne višejezičnosti i analizirati je kroz hrvatske kurikulume te dati smjernice za njezin održivi razvoj u svrhu stvaranja kompetentnih višejezičnih korisnika stranih jezika.

Ključne riječi: individualna višejezičnost, hrvatski obrazovni sustav, kurikulumi, materinski jezik, strani jezici

\section{Uvod}

Nedavni statistički podaci koji nam govore da postoji 6000 jezika u 193 zemalja svijeta (Wei, Moyer, 2008) upućuju na to da višejezičnost postaje norma modernoga društva. Naravno, stanovnici nekih višejezičnih zemalja (pr. Belgija, Švicarska) ne moraju se nužno smatrati višejezičnim osobama, dok opet stanovnici pretežito jednojezičnih zemalja (pr. Francuska, Njemačka, a isto tako i Hrvatska) postaju iz dana u dan višejezičnima (ibid.).

Kemp $(2009,15)$ smatra da višejezičari ne moraju posjedovati jednako znanje, kao i kontrolu svih jezika koje znaju, te raspravlja o nekoliko problemskih pitanja važnih za određenje poznavanja više jezika. Ona se odnose na stupanj jezičnoga znanja u svim jezicima kojima 
pojedinac vlada, stupanj funkcionalne sposobnosti, odnosno upotrebe jezika u komunikacijske svrhe, jezičnoga kriterija zajedničkoga shvaćanja, kulturološke i političke kriterije, neke afektivne kriterije i pismenost. Slično stajalište dijele Wei, Moyer $(2008,4)$ koji opisuju višejezičnoga pojedinca kao osobu koja može komunicirati na više od jednoga jezika, i to, aktivno (govorom i pismom) ili pasivno (slušanjem i čitanjem). Stoga možemo zaključiti da je osoba višejezična neovisno o njezinoj inojezičnoj kompetenciji, a isto tako neovisno o statusu pojedinih jezika u društvu i kontekstu njihove upotrebe.

U suvremenoj literaturi razlikujemo plurilingvalnost ili višejezičnost i multilingvalnost ili mnogojezičnost. Pojmovi se često nedosljedno rabe te će se ponekad nazivom multilingvalnost koristiti i kada se misli na višejezičnost.

Pod pojmom multilingvalnost ili mnogojezičnost (engl. multilingualism) označava se mogućnost učenja različitih jezika u bilo kojoj odgojno-obrazovnoj ustanovi ili različitim multikulturalnim sredinama koji pritom ne moraju nužno interferirati (Pavličević Franić, 2006, 2), a pod pojmom plurilingvalnost ili višejezičnost (engl. plurilingualism) ističe se međujezična povezanost, ispreplitanje i međudjelovanje različitih jezičnih kodova u istoga govornika koji se koristi svojim postojećim inojezičnim znanjem u ovladavanju novim jezikom (Pavličević Franić, 2006; Zajednički europski referentni okvir za jezike, 2005, 4). Za potrebe našega rada koristit ćemo se već uvriježenim nazivom višejezičnost jer se smatra krovnim nazivom i za multilingvalnost, polilingvalnost i plurilingvalnost (Medved Krajnović, 2010, 6).

Naglasak će isključivo biti na individualnoj višejezičnosti imajući tada u vidu psiholingvistički aspekt ovladavanja stranim jezicima u okviru formalnoga obrazovanja. Osim pojma individualne višejezičnosti u literaturi nalazimo još dva oblika višejezičnosti: institucionalnu i teritorijalnu. Dok se individualna višejezičnost definira prvenstveno s obzirom na raslojenost verbalnoga repertoara pojedinca, institucionalnom višejezičnošću naziva se istovremena prisutnost dvaju jezika u upravnim tijelima gradova, okruga i drugih teritorijalnih jedinica, ali i pojedinih organizacija koje za odnose s javnošću rabe više od jednoga jezika. Teritorijalna višejezičnost se odnosi na ona društva u kojima je jezična stratifikacija usko povezana s teritorijalnom 
rasprostranjenošću pojedinačnih jezičnih zajednica (Banjavčić, Erdeljac, 2009, 19). Oba oblika, i institucionalna i teritorijalna višejezičnost, vezana su prvenstveno za sociolingvistički aspekt jezika, za razliku od individualne višejezičnost koja podrazumijeva psiholingvistički aspekt jezika.

U sljedećem ćemo poglavlju prikazati vrste individualne višejezičnosti o kojima se raspravlja u suvremenim istraživačkim krugovima ovisno o kontekstu istraživanja višejezičnosti.

\section{Vrste individualne višejezičnosti}

Königs (2000 u Neuner, 2004, 15) razlikuje tri vrste individualne višejezičnosti: retrospektivnu višejezičnost (engl. retrospective plurilingualism), retrospektivno-prospektivnu višejezičnost (engl. retrospective-prospective plurilingualism) i prospektivnu višejezičnost (engl. prospective plurilingualism). Prva vrsta višejezičnosti, tj. retrospektivna odnosi se na dvojezične govornike koji dolaskom na nastavu već posjeduju znanje drugoga jezika (J2), odnosno znanje jezika koji je i predmet nastave i prema tome su u prednosti naspram ostalih učenika. Retrospektivnoprospektivna višejezičnost podrazumijeva višejezične govornike koji su dolaskom na nastavu u prednosti naspram ostalih učenika u inojezičnom znanju, no niti jedan od njihovih jezika nije predmet nastave, već daljnjim učenjem trećega ili dodatnoga jezika razvijaju svoju višejezičnost. Prospektivna višejezičnost specifična je za učenike koji su dolaskom na nastavu jednojezični govornici i svoju višejezičnost razvijaju učenjem ponajprije prvoga stranog jezika u školi.

Ova posljednja vrsta višejezičnosti, tj. prospektivna višejezičnost, karakteristična je za većinu europskih škola, kao i Hrvatsku, gdje se polaskom u školu većina učenika po prvi puta susreće s učenjem jednoga ili više stranih jezika.

Imajući na umu didaktiku višejezičnosti, tj. učenje i podučavanje inih jezika u obrazovanju, neke od značajki novoga poimanja višejezičnosti koje navodi Neuner (2004, 15-16) su da: učenjem nekoliko jezika u školi učenik u učenju svakoga novog jezika razvija već postojeće iskustvo u učenju jezika, kao i da nije nužno postići kompetenciju blisku izvornomu govorniku u svakome od jezika, te stupanj kompetencije i jezični profil u 
svakome od jezika je različiti. Prema tome, višejezičnim se korisnikom ne može više smatrati osoba koja dostigne razinu jezičnoga umijeća blisku umijeću izvornoga govornika, a što se donedavno isticalo u stručnim krugovima (Medved Krajnović, 2010, 8), već je danas prihvatljivo da korisnik inih jezika može posjedovati različite vještine u svim jezicima prema danim potrebama.

Kada govorimo o kronološkom ovladavanju jezicima u hrvatskome obrazovnom sustavu riječ je uglavnom o konsekutivnoj višejezičnosti (Cenoz, 2000, 40), a uključuje ovladavanje ponajprije materinskim jezikom (J1), te ovladavanje inim jezicima nakon J1 (J2; J3 itd.). Takav primjer nalazimo u većini hrvatskih škola gdje učenici u prvome razredu osnovne škole uče prvi strani jezik, a u četvrtome razredu uče drugi strani jezik po izboru. Polaskom u srednju školu, učenici će nastaviti učiti već postojeće strane jezike, a ovisno o usmjerenju srednje škole, njihov će se dotadašnji inojezični repertoar obogaćivati i učenjem dodatnih stranih jezika. Jezični prostor u Hrvatskoj obilježen je i hrvatsko-talijanskom dvojezičnošću u Istri. Stoga će učenici nekih dijelova toga područja u prvome razredu osnovne škole učiti prvi strani jezik (engleski ili njemački), u drugome razredu jezik sredine ili drugi strani jezik (talijanski jezik), a treći strani jezik neki će po izboru učiti u četvrtome razredu osnovne škole, a neki u prvome razredu srednje škole (engleski ili njemački, a u nekim usmjerenjima srednje škole i francuski ili španjolski). Osim u Istri, i u nekim drugim područjima Hrvatske, gdje je prisutno manjinsko stanovništvo, učenicima se pruža mogućnost obrazovanja i na manjinskim jezicima. Takvo obrazovanje sastoji se od nekoliko osnovnih modela i posebnih oblika školovanja na jeziku i pismu nacionalnih manjina, a uključuje MODEL A - nastavu na jeziku i pismu nacionalnih manjina; MODEL B - dvojezičnu nastavu; MODEL C - njegovanje jezika i kulture, kao i oblik nastave u kojem se jezik nacionalne manjine uči kao jezik sredine, i posebne oblike nastave (ljetna škola, zimska škola, dopisno-konzultativna nastava). Budući da se naš rad bavi opisom individualne višejezičnosti u kontekstu hrvatskog obrazovnog sustava, ne uzimajući u obzir predviđene modele dvojezične nastave za nacionalne manjine u Hrvatskoj, usredotočit ćemo se tada samo na analizu nastavnih planova i programa učenika u osnovnim i srednjim školama koji pohađaju redovito školovanje na hrvatskom kao materinskom jeziku 
i pritom uče kroz različite cikluse svoga obrazovanja različite strane jezike.

\section{Oblikovanje nastave materinskoga i stranih jezika u osnovnim i srednjim školama u Hrvatskoj}

Dva osnovna dokumenta koja daju glavne, teorijski i praktično utemeljene, smjernice stručnjacima (ravnateljima, nastavnicima, stručnim suradnicima) za provedbu nastave u svim područjima osnovnoškolskoga i srednjoškolskoga obrazovanja na nacionalnoj razini su Nastavni plan i program za osnovnu školu (2006) i Nacionalni okvirni kurikulum za predškolski odgoj i obrazovanje te opće obvezno i srednjoškolsko obrazovanje (2011). Oba dokumenta u opisu plana i programa u jezičnome području pokazuju usklađenost sa Zajedničkim europskim referentnim okvirom za jezike: učenje, podučavanje i vrednovanje (ZEROJ) (2005), dokument koji je za potrebe hrvatskoga govornog područja preveden $\mathrm{s}$ engleskoga na hrvatski jezik, a originalni naziv dokumenta je Common European Framework of Reference for Languages: Learning, teaching and assessment (Council of Europe 2001). Namjera toga europskoga dokumenta bila je stvoriti temelj za oblikovanje jezičnih planova i programa, davanje smjernica za kurikulum te vrednovanje i stvaranje jezičnih materijala $\mathrm{u}$ cijeloj Europi (Council of Europe, 2001).

Cilj našega rada jest analizirati postojeće kurikularne dokumente, kako u osnovnoj tako i u srednjoj školi u jezično-komunikacijskome području i ukazati na potrebu njihovoga unaprjeđenja s ciljem većega prožimanja individualne višejezičnosti i time poboljšanja kvalitete nastave stranih jezika u višejezičnome kontekstu. Stoga ćemo opisati nekoliko školskih kurikuluma osnovnih i srednjih škola s aspekta individualne višejezičnosti.

\section{Nastavni plan i program za osnovnu školu - hrvatski jezik i strani jezici}

Nastavni plan i program za osnovnu školu (NPP) (2006) najnoviji je dokument koji je proizišao iz Hrvatskoga nacionalnog obrazovnog standarda (HNOS) (2005) čiji su neki od ključnih ciljeva nastave u 
osnovnoj školi: rasterećenje učenika smanjivanjem udjela enciklopedijskih sadržaja, nastava utemeljena na procesu poučavanja umjesto isključivo na predavanju, poučavanje usmjereno prema učeniku te osposobljavanje za cjeloživotno učenje (HNOS, 2005, 12).

Kada govorimo o ovladavanju inim jezicima, osobito s psiholingvističkoga aspekta, neizostavno je spomenuti i ulogu materinskoga jezika koji može posredno ili neposredno utjecati na razvoj jezične i komunikacijske kompetencije i u inome jeziku. Stoga ćemo se osvrnuti ponajprije na ciljeve i zadaće materinskoga jezika u okviru NPP-a za osnovne škole (2006) i prikazati povezanost nastave materinskoga jezika s inim jezicima koje učenik uči kroz osnovnoškolsko obrazovanje.

Budući da se radi o nastavi hrvatskoga kao materinskoga jezika, ciljevi i zadaće u sklopu nastave hrvatskoga jezika u skladu su s potrebama učenika kroz svih osam godina, koliko traje obvezno osnovnoškolsko obrazovanje. Važno je istaknuti da se zadaće i sadržaji predmeta prema načelu međupredmetnoga povezivanja (a što je osnovna svrha HNOS-a u osnovnoj školi) funkcionalno povezuju s ostalim nastavnim područjima. Prema NPP-u za osnovne škole (2006, 25), temeljni je cilj nastave hrvatskoga jezika osposobiti učenike za jezičnu komunikaciju koja im omogućuje ovladavanje sadržajima svih nastavnih predmeta i uključivanje u cjeloživotno učenje. Između ostaloga, to podrazumijeva i uključivanje materinskoga jezika u nastavu stranoga jezika. Neke od zadaća koje se također navode u planu i programu za hrvatski jezik su osvijestiti kod učenika razliku između standardnoga jezika i zavičajnih idioma te postupno usvajanje hrvatskoga jezičnog standarda. Odraz je to zaključka da jednostrano normativno dijete $u$ ranoj fazi jezičnoga učenja poznaje samo svoj organski (rođeni, majčin, okolinski, zavičajni...) idiom, odnosno govor sredine koja ga okružuje, ali polaskom u obrazovne ustanove, postaje nenormativno višejezična osoba (Pavličević Franić, 2006, 3). Time se kod učenika budi svijest i o poznavanju drugih novih jezičnih sustava s kojima dolaze u doticaj kroz obrazovanje.

$\mathrm{U}$ opisu stranih jezika zamjećuju se konkretne smjernice $\mathrm{u}$ povezivanju materinskoga i stranih jezika kroz osnovnoškolsko obrazovanje. Takve smjernice vidljive su prije svega u HNOS-u za predmet Engleski kao prvi strani jezik i drugi strani jezik $(2005,7)$ gdje se eksplicitno ukazuje 
na sljedeće načelo: koristiti se stranim jezikom kolikogod je to moguće, a materinski jezik onoliko koliko je to potrebno. Takvo načelo objašnjava se dvama različitim ulogama materinskoga jezika u ovladavanju stranim jezikom. Materinski jezik tada ima dvojaku ulogu - ulogu metajezika kojim eventualno objašnjavamo jezične strukture onda kada ih učenici/učenice na stranome jeziku ne razumiju te ulogu sustava jezika na kojem gradimo daljnja objašnjenja i upućujemo na sličnosti i razlike pojedinih struktura u stranome i materinskome jeziku. Materinskim se jezikom na početnoj razini učenja po potrebi mogu pojasniti kulturno civilizacijski sadržaji (ibid.).

U objašnjavanju svrhe i obilježja nastave stranih jezika prema NPP-u za osnovne škole, koji je i sastavni dio HNOS-a, navodi se kako se europske institucije zauzimaju za višejezičnost građana Europe, a što podrazumijeva da bi se tijekom obveznoga obrazovanja svakom učeniku u EU trebalo omogućiti učenje barem dvaju stranih jezika, odnosno formula: „materinski jezik plus dva strana jezika“ (Horvatić Čajko, 2012, 4). Takav pristup karakterističan je i za većinu hrvatskih škola. Ono što je važno naglasiti za razvoj individualne višejezičnosti u kontekstu hrvatskoga obrazovnog sustava jest povezivati postojeće znanje materinskoga i ostalih stranih jezika, ali istovremeno povezivati i postojeća znanja jednoga stranoga jezika u učenju nekoga drugoga stranog jezika, odnosno ukazivati na sličnosti i razlike među stranim jezicima. Prema tome, jedan od obrazovnih ciljeva u tome smjeru prikazan je i u NPP-u za osnovnu školu u kojemu se ističe da učenike treba poticati da nepoznate riječi i izričaje prvo pokušaju razumjeti primjenom postojećega znanja, konteksta i pomoću strategija za razumijevanje. Što se tiče odgojnih ciljeva, jedan od njih također uključuje da se kod učenika razvija svijest o mnogojezičnosti i višejezičnosti te međukulturalnim sličnostima i razlikama.

U konkretnome opisu programa za engleski, njemački, francuski i talijanski kao prve strane jezike govori se uglavnom o povezivanju nastavnih sadržaja s hrvatskim kao materinskim jezikom, vjerojatno jer se radi o stranome jeziku s kojim se učenici po prvi puta susreću u osnovnoškolskome obrazovanju. Međutim, zanimljivo je primijetiti da se kod predmeta njemački kao 1. strani jezik od 4. do 8. razreda osnovne škole, u dijelu gdje se opisuju strategije učenja i služenja znanjem, govori 
o tome da će učenici međusobno uspoređivati strane jezike, služiti se znanjem materinskoga jezika i stranih jezika koje učenik uči. Jednako tako je navedeno i za njemački kao 2. strani jezik od 4. do 8. razreda, a što nije slučaj u opisu engleskoga kao 2. stranog jezika. U opisu francuskoga kao 1. stranog jezika također se u kontekstu strategija učenja i služenja znanjem upućuje na uočavanje sličnosti i razlika između francuskoga i hrvatskoga jezika ili među drugim stranim jezicima, ali tek u 8. razredu (NPP, 2006, 177). Jedino u opisu vještine slušanja od 5. do 6. razreda za francuski kao 2. strani jezik navodi se uočavanje različitoga izgovora glasova i glasovnih skupina francuskoga jezika u odnosu na hrvatski jezik/prvi strani jezik, a u dijelu strategija učenja i služenja znanjem u 8. razredu za francuski kao 2. strani jezik još se navodi osamostaljivanje učenika za služenje rječnikom u udžbeniku, slikovnim, dvojezičnim, jednojezičnim i višejezičnim rječnikom, što je vrlo korisno u promicanju individualne višejezičnosti.

$\mathrm{U}$ uvodnome dijelu opisa programa za talijanski jezik od izuzetnoga je značaja tvrdnja da će u nastavi talijanskoga kao stranoga jezika u osnovnim školama učitelji poticati učenike da sami pronađu međukulturalne i međujezične utjecaje. To se prije svega odnosi na osvještavanje učenika o supostojanju i drugih jezičnih sustava čije im znanje i iskustvo može pomoći u ovladavanju novim jezičnim sustavom. No, tek od 7. do 8. razreda za talijanski kao 1. strani jezik spominje se uočavanje sličnosti i razlika između stranoga i materinskoga jezika ili među stranim jezicima, a u istim razredima za talijanski kao 2. strani jezik također se navodi u strategijama učenja i služenja znanjem - uočavanje i povezivanje sličnosti i razlika u jezičnim ustrojima (strani - materinski jezik; strani strani jezik), što nije slučaj i u ostalim razredima za isti jezik.

Ovakav nejednak omjer prilikom opisa različitih jezika kada se dovodi u pitanje njihovo međusobno povezivanje očekivan je posebno kod usporedbe prvih i drugih stranih jezika jer svakako učenici posjeduju već neko iskustvo u učenju jezika kada započinju s učenjem drugoga stranog jezika.

Međutim, ono što je začuđujuće jest da se kod pojedinoga stranog jezika ukazuje na različiti pristup ili se čak ne spominje međujezično povezivanje. Stoga je potrebno u kreiranju nastavnih planova i programa voditi računa o zastupljenosti jednakih strategija u smislu razvoja 
učenikovih jezičnih kompetencija u svim jezicima koje se uče.

\section{Nacionalni okvirni kurikulum za predškolski odgoj i obrazovanje te opće obvezno i srednjoškolsko obrazovanje - jezično-komunikacijsko područje}

Središnji dio Nacionalnoga okvirnoga kurikuluma (NOK), kako se u uvodnome dijelu dokumenta navodi, čine učenička postignuća za odgojno-obrazovna područja, razrađena po odgojno-obrazovnim ciklusima te opisi i ciljevi međupredmetnih tema koje su usmjerene na razvijanje ključnih učeničkih kompetencija. Dokument je također osnova za izradbu nastavnoga plana primjerenoga opterećenju učenika, razradbu predmetne strukture unutar odgojno-obrazovnoga područja, određivanje predmeta i modula jezgrovnoga i diferenciranoga (razlikovnoga) kurikuluma (izbornih predmeta i modula), te školskoga kurikuluma (NOK, 2011, 16). Bez obzira na to što je prošlo već četiri godine od izdavanja ovoga dokumenta koji, između ostaloga, čini temelj za razvoj suvremenih nastavnih planova $i$ programa, na razini srednjih škola to još nije postignuto. Profesori srednjih škola još se uvijek oslanjaju na postojeće neosuvremenjene programe iz 1990-ih godina i prema tome grade svoje sadržaje i metode rada na nastavi stranih jezika. Tako u Glasniku Ministarstva kulture i prosvjete RH (GMKP) u prikazu nastavnih programa za gimnazije u području stranih jezika, pri opisu svrhe i cilja nastave stranih jezika daju se samo neke od tvrdnji koje ukazuju na potrebu za razvoj višejezičnosti u nastavi stranih jezika. Jedna tvrdnja je da poučavanje stranih jezika djeluje istodobno na razvoj lingvističkoga mišljenja koje pomaže u učenju i razumijevanju sustava i hrvatskoga i drugih jezika. Druga se tvrdnja nadovezuje na prethodnu ističući da je poučavanje stranoga jezika u skladu s aktualnim težnjama za očuvanjem bogatstva različitosti mnogojezične Europe te kulturoloških sličnosti i razlika u stvaranju osjećaja pripadnosti građanstvu Europe (GMKP, 1994, 22). Daljnjim uvidom u programsku građu GMKP-a za engleski, njemački, francuski i ruski kao prve strane jezike ne pokazuje se izravna usmjerenost na razlikovanje među stranim jezicima, osim $u$ prikazu jezičnih vještina. Naime, u dijelu gdje se spominje i prevođenje kao jedna od jezičnih vještina govori se da će učenici prevoditi tekstove $s$ 
prvoga stranog jezika na hrvatski, a kod nekih stranih jezika i uočavati te spoznavati razlike u strukturama i načinima izražavanja u hrvatskome i nekom od stranih jezika.

Izloženost nekim stranim jezicima kroz medije izvan škole, neovisno o formalnome učenju tih stranih jezika u školi, može se uzeti u obzir i kod učenja prvih stranih jezika u školama, te postepeno osvještavati učenike o poznavanju postojećih jezičnih sustava i u formalnome učenju nekoga drugoga stranog jezika u školi, osobito kada se radi o srodnim jezicima.

U opisu zadaća drugih stranih jezika situacija je malo drugačija. Navodi se kako će učenici uočiti posebnosti sustava drugoga stranoga jezika u odnosu na hrvatski i prvi strani jezik. Opis je opravdan jer učenici već posjeduju neko iskustvo u formalnome učenju jezika. Međutim, ukazivanje na povezanost među jezicima na primjeru engleskoga, njemačkoga, francuskoga, ruskoga, španjolskoga i talijanskoga kao drugih stranih jezika nije uočeno u prikazu programske građe. Jedino se kod opisa prevođenja ukazuje na uočavanje razlika između stranoga jezika i hrvatskoga kao materinskoga. To je rezultat i didaktičkih uputa koje se daju na kraju prikaza programske građe za strane jezike, a prema kojima se u nastavi u pravilu rabi samo strani jezik, a materinski samo kada se trebaju osvijestiti razlike u odnosu na strani jezik i provjeriti jesu li učenici nešto razumjeli (GMKP, 1994, 57).

Primjere takvih nastavnih planova i programa za srednje škole ne nalazimo samo u gimnazijskim usmjerenjima već i ostalim usmjerenjima četverogodišnjih strukovnih i tehničkih škola, ali i trogodišnjih.

S perspektive europske jezične politike kojoj teži i Hrvatska, oni su neprihvatljivi i nikako ne pokazuju otvorenost prema višejezičnoj izgradnji hrvatskoga obrazovnog sustava. Pokušaj izrade jednoga općeg kurikuluma na nacionalnoj razini, uključujući sve stupnjeve obrazovanja (od predškolskoga do srednjoškolskoga), kao što je NOK u Hrvatskoj, dobar je početak k osuvremenjivanju nastavnih planova i programa, ali koje tek treba stvoriti.

U jezično-komunikacijskome području NOK-a općega obveznoga i srednjoškolskoga obrazovanja prožima se opća konstatacija glede materinskoga, u našemu slučaju hrvatskoga jezika učenika, a to je da je 
materinski jezik osnova za ovladavanje drugim jezicima. Stjecanjem višejezične i međukulturne kompetencije razvija se svijest pojedinca o potrebi ovladavanja drugim jezicima i upoznavanja njihovih kultura te potiče poštivanje različitosti i toleranciju (NOK, 2011, 55). U svim ciklusima obrazovanja (od 1. razreda osnovne škole pa sve do završnoga razreda srednje škole) takav je prikaz očit za hrvatski jezik s naznakom da će učenici prepoznati i poštovati obilježja hrvatske, svoje i drugih kultura u svojemu bližemu okružju te ih izraziti kroz sve četiri jezične vještine: slušanje, čitanje, govorenje i pisanje. Radi se o dosta općenitome shvaćanju individualne višejezičnosti u kojoj zapravo nije iskazana prava potreba za povezivanjem jezika koja je neophodna za razvoj višejezične kompetencije. Naravno, kako je riječ o materinskome jeziku, takvo stajalište može biti prihvatljivo.

U opisu stranih jezika, povezivanje stranoga jezika s materinskim započinje tek u drugome ciklusu obrazovanja (5. razred osnovne škole), ali se ne opisuje, niti upućuje na svijest učenika o iskoristivosti postojećega znanja među stranim jezicima, a što je ključni temelj razvoja individualne višejezičnosti čemu teži europsko društvo.

Analiza NOK-a daje samo jedan dio smjernica koje treba nadalje proširiti i upotrijebiti u kreiranju novih nastavnih planova i programa za srednju školu, a što trenutni programi ne pružaju.

Iz NOK-a proizlaze i školski kurikulumi za pojedinu školu čije su sastavnice osim izborne, dodatne i dopunske nastave za pojedine predmete, terenska i izvanučionička nastava i raznovrsne aktivnosti i projekti koji se provode kroz jednu školsku godinu. Školski kurikulumi važan su pokazatelj uloga škola u kreiranju odgojno-obrazovnoga rada čija je glavna zadaća poticati učenike na iskoristivost njihova znanja i umijeća kroz paradigmu različitih izvora, a sve u svrhu razvijanja novih vještina i samostalnoga učenja.

\section{Školski kurikulumi u osnovnim i srednjim školama}

Analiza školskih kurikuluma uključila je pet kurikuluma za osnovne hrvatske škole i pet kurikuluma za srednje hrvatske škole (dvije škole gimnazijskoga usmjerenja i tri strukovne škole) u Istarskoj županiji. 
$\mathrm{U}$ analizi školskih kurikuluma za pet istarskih osnovnih škola primjećuje se da je u školama u redovnoj nastavi zastupljena i dodatna nastava iz hrvatskoga, engleskoga, talijanskoga ili njemačkoga jezika (ovisno o stranome jeziku koji uče, talijanski ili njemački). Međutim, slaba je zastupljenost aktivnosti isključivo vezanih za promicanje višejezičnosti kroz razna obilježavanja dana i projekata pojedinih jezika koje učenici uče u školi. U jednoj je školi zabilježen izlet učenika u Beč kao dio terenske nastave, što podrazumijeva razvoj jezične i komunikacijske kompetencije učenika u njemačkome jeziku u stvarnim situacijama, dok u drugoj školi nije uključena niti jedna aktivnost u kojoj bi učenici mogli razvijati svoju individualnu višejezičnost. Samo jedna aktivnost u kojoj je predviđena međupredmetna korelacija bilježi se u školi koja ima u planu organizirati terensku nastavu za povijest, hrvatski jezik, engleski jezik i vjeronauk u 6 . i 7. razredu. Slične primjere ne dijele ostale dvije škole, u čijim se školskim kurikulumima navodi nešto više jezičnih aktivnosti, poput obilježavanja Europskoga dana jezika, Dana hrvatskoga jezika, Dana čarobnih riječi, kao i uključenost jedne škole u projekt „Souvenirs for Europe“.

Što se tiče srednjih škola, prikaz indirektnoga promicanja individualne višejezičnosti u okviru školskih kurikuluma pojedinih škola mnogo je opsežniji, na način da postoji više aktivnosti i projekata koji vode $u$ tome smjeru. Analizom pet srednjih škola različitih usmjerenja (gimnazije, tehničke škole, strukovne i industrijsko-obrtničke) s područja Istarske županije zamjećuje se veća mogućnost uključivanja učenika u jezičnokomunikacijsko područje, kako u sklopu hrvatskoga kao materinskoga jezika, tako i stranih jezika: engleskoga, njemačkoga i talijanskoga. Osim dodatne i fakultativne nastave materinskoga i stranih jezika, kao i natjecanja iz tih jezika, u školskim kurikulumima srednjih škola navode se i razne izvannastavne aktivnosti stranih jezika (Cambridge University Press natjecanje), obilježavanja Europskoga dana jezika, Dana hrvatskoga jezika, Međunarodnoga dana materinskoga jezika, kao i razni međunarodni projekti u kojima su učenici aktivno uključeni u razvijanje jezičnih vještina iz pojedinih jezika, ali i povezivanje jezično-kulturnih sadržaja različitih jezika koje uče s vlastitom kulturom i jezikom. Također se spominju stručne ekskurzije u zemlje talijanskoga i njemačkoga govornog područja. Razvoj individualne višejezičnosti, osim navedenoga, u jednoj školi izrazito je očit 
u jednome školskom projektu pod nazivom „Vještine pripovijedanja“, u kojemu učenici čitaju razne književne tekstove i raspravljaju o njima na hrvatskome i stranim jezicima. Time se njeguje jezično stvaralaštvo, ne samo kroz materinski jezik već i ostale strane jezike.

Usporedimo li osnovne i srednje škole prema školskim kurikulumima s obzirom na uključenost učenika u jezične aktivnosti, primjećujemo da je u srednjim školama predviđeno mnogo više aktivnosti i projekata s ciljem razvoja individualne višejezičnosti. Razlog tomu mogu biti i određena usmjerenja pojedinih srednjih škola koja usmjeravaju učenike na kasniji profesionalni razvoj i otvaraju im put k oblikovanju vlastitoga cjeloživotnog učenja.

Svakako, nužno je bolje poraditi na jezičnim sadržajima školskih kurikuluma, osobito u osnovnim školama, jer stvaranjem dobroga temelja u primarnome obrazovanju, učenicima je tada u kasnijim etapama obrazovanja lakše razvijati svoje postojeće i nove jezične kompetencije, bilo u nastavnome ili izvannastavnome kontekstu.

\section{Zaključak}

Individualna višejezičnost smatra se prvim uvjetom za miran suživot raznih naroda, a treba uslijediti promjenom tradicionalnih načina odabira jezika u školama, kao i izdiferenciranosti ciljeva učenja u nastavi stranoga jezika (Velički, 2007, 95). U hrvatskome obrazovnom sustavu tomu može pridonijeti ponuda širega spektra učenja stranih jezika u školama, što znači da škole mogu nuditi i više različitih stranih jezika nego što kurikulum zahtijeva. To se posebno odnosi na škole koje prema svome planu i programu imaju više od dva strana jezika u ponudi, poput trogodišnjih i četverogodišnjih strukovnih škola (sektor - ugostiteljstvo i turizam) i pojedinih gimnazija (opće, jezične, turističke). Odabir različitih stranih jezika može ovisiti i o dostupnim nastavnicima čiji jezični profil uključuje poznavanje najmanje dva strana jezika. Tako se može omogućiti nastavnicima, koji osim na primjer talijanskoga ili engleskoga kao prvih stranih jezika, mogu poučavati i druge strane jezike iz svoje jezične kombinacije, poput ruskoga ili španjolskoga.

Prema Prvom europskom istraživanju jezičnih kompetencija (2012, 
60), novi pristup u poučavanju stranih jezika za koji se zalaže Europska unija, obuhvaća širok holistički pristup poučavanju u kojemu se ističe komunikacijska sposobnost i višejezično razumijevanje te se naglasak stavlja na produktivnu komunikacijsku sposobnost.

Kao važnu smjernicu u promicanju individualne višejezičnosti posebno bismo istaknuli ulogu škola i samih nastavnika. Ono što škole mogu je bolje poraditi na osmišljavanju raznih aktivnosti u školskom kurikulumu u jezično-komunikacijskome području i prema tome graditi i svoj višejezični identitet, dok bi uloga nastavnika stranih jezika trebala biti usmjerena na stvaranje višejezičnoga razrednog diskursa, u kojemu se ne poučava samo određeni strani jezik, već se kontrastivno upućuje na sličnosti i razlike, ne samo među materinskim i stranim jezikom već i stranim jezicima koji su učenicima na raspolaganju, neovisno o tome ovladavaju li određenim stranim jezicima u formalnome ili neformalnome okruženju. Upotrebom informacijske i komunikacijske tehnologije u nastavi koja je sve više prisutna u poučavanju stranih jezika, nastavnici mogu također usmjeravati učenike na upotrebu medija u učenju stranih jezika izvan škole. Time se otvara i mogućnost za neformalno učenje jezika, na koji nastavnici ne mogu direktno utjecati u kućnome i životnome okruženju učenika.

Analizom kurikularnih dokumenata za osnovne i srednje škole dolazimo do zaključka da je potrebno detaljno razraditi i uskladiti opće i individualne ciljeve i zadaće, ishode učenja, programske sadržaje, kao i međupredmetne veze $u$ jezično-komunikacijskome području na makro i mikro razini. Na makro razini neophodna je cjelovita kurikularna reforma postojećih dokumenata koji bi poslužili kao temelj ostalim dokumentima na mikro razini - školskim kurikulumima. Na taj će način doći do izražaja razvoj individualne višejezičnosti, a istovremeno i održavanje višejezične kompetencije kod učenika u osnovnim i srednjim školama u Hrvatskoj.

\section{Literatura}

BANJAVČIĆ, M., ERDELJAC, V., 2009, Višejezičnost i identitet, Monitor ISH, 11(1), 7-34.

CENOZ, J., 2000, Research on Multilingual Acquisition. U: Cenoz, 
J., Jessner, U. (ur.) English in Europe: The Acquisition of a Third Language, Multilingual Matters Ltd., Clevedon, Buffalo, Toronto, Sydney, 39-53.

COUNCIL OF EUROPE, 2001, Common European Framework of Reference for Languages: Learning, Teaching, Assessment, Language Policy Unit, Strasbourg. http://www.coe.int/t/dg4/linguistic/Source/Framework_ EN.pdf (18/7/2007)

EUROPSKA KOMISIJA, 2012, Prvo europsko istraživanje jezičnih kompetencija, Nacionalni centar za vanjsko vrednovanje obrazovanja, Zagreb. http://dokumenti.ncvvo.hr/ESLC/Prvo_istrazivanje_jezicnih.pdf $(13 / 11 / 2013)$

GLASNIK MINISTARSTVA KULTURE I PROSVJETE REPUBLIKE HRVATSKE, 1994, Ministarstvo kulture i prosvjete Republike Hrvatske, Zagreb.

HORVATIĆ ČAJKO, I., 2012, Uloga višejezične kompetencije u učenju i poučavanju drugoga stranoga jezika - njemački jezika kao L3. Neobjavljena doktorska disertacija. Sveučilište u Zagrebu, Filozofski fakultet, Zagreb.

VODIČ KROZ HRVATSKI NACIONALNI OBRAZOVNI STANDARD ZA OSNOVNU ŠKOLU, 2005, Ministarstvo znanosti, obrazovanja i športa, Zagreb. os-drazice.skole.hr/upload/os-drazice/.../6/ vodic\%20kroz\%20hnos.doc (4/5/2015)

JESSNER, U., 2008, A DST Model of Multilingualism and the Role of Metalinguistic Awareness, The Modern Language Journal, 92(2), 270-283.

NACIONALNI OKVIRNI KURIKULUM ZA PREDŠKOLSKI ODGOJ I OBRAZOVANJE TE OPĆE OBVEZNO I SREDNJOŠKOLSKO OBRAZOVANJE, 2011, Ministarstvo znanosti, obrazovanja i športa, Zagreb. file://C:/Documents\%20and\%20Settings/Marina/My\%20Documents/ Downloads/Nacionalni_okvirni_kurikulum_web_listopad_2011\%20(3). pdf $(30 / 12 / 2014)$

NASTAVNI PLAN I PROGRAM ZA OSNOVNE ŠKOLE, 2006, Ministarstvo znanosti, obrazovanja i športa, Zagreb. file://C:/ Documents\%20and\%20Settings/Marina/My\%20Documents/Downloads/ Nastavni\%20plan\%20i\%20program\%20za\%20OS\%20(2).pdf (4/3/2015)

NEUNER, G., 2004, The concept of plurilingualism and tertiary language didactics. U HUFEISEN, B., NEUNER, G. (ur.) The Plurilingualism 
Project: Tertiary Language Learning - German after English, Council of Europe, Strasbourg, 13-34.

MEDVED KRAJNOVIĆ, M., 2010, Od jednojezičnosti do višejezičnosti: Uvod u istraživanja procesa ovladavanja inim jezikom, Leykam international d.o.o., Zagreb.

PAVLIČEVIĆ-FRANIĆ, D., 2006, Jezičnost i međujezičnost između sustava, podsustava i komunikacije, $L A H O R, 1,1-14$.

VELIČKI, D., 2007, Nova višejezičnost i učenje stranih jezika kao dio jezične politike, Metodički ogledi, 14(1), 93-103.

ZAJEDNIČKI EUROPSKI REFERENTNI OKVIR ZA JEZIKE: UČENJE, POUČAVANJE, VREDNOVANJE, 2005, Vijeće Europe, Odjel za suvremene jezike, Strasbourg, Školska knjiga, Zagreb.

WEI, L., MOYER, M. G., 2008, Research Perspectives on Bilingualism and Multilingualism. U: WEI, L., MOYER, M. G. (ur.) Research Methods in Bilingualism and Multilingualism. Blackwell Publishing Ltd, USA, UK, Australia, 3-17.

\section{Il plurilinguismo individuale nel contesto dell'educazione Croata}

Il plurilinguismo individuale viene definito soprattutto in base alla stratificazione del repertorio verbale di un individuo (Banjavčić, Erdeljac, 2009, 18). Così Königs (2000 in: Neuner, 2004, 15) distingue 3 tipi di plurilinguismo individuale: il plurilinguismo retrospettivo (ingl. retrospective plurilingualism), che si riferisce ai parlanti bilingui che al momento della frequentazione delle lezioni già possiedono la conoscenza di una seconda lingua (L2), ovvero, conoscono già la lingua oggetto dell'insegnamento, e quindi, sono avvantaggiati rispetto ad altri studenti; il plurilinguismo retrospettivo - prospettivo (ing. retrospective - prospective plurilingualism), che si riferisce ai parlanti plurilingui che al momento della frequentazione delle lezioni sono avvantaggiati rispetto agli altri studenti nelle loro conoscenze di altre lingue (L2, L3, LS), ma nessuna delle quali è oggetto delle lezioni e sviluppano il loro plurilinguismo con ulteriore apprendimento della terza lingua o di una lingua aggiuntiva; e 
infine, il plurilinguismo prospettivo (ingl. prospective plurilingualism) che si riferisce agli studenti che cominciano a frequentare le lezioni come monolingui e sviluppano il loro plurilinguismo soprattutto tramite l'apprendimento scolastico della prima lingua straniera. Quest'ultimo tipo di plurilinguismo, prospettivo, è caratteristico della maggior parte delle scuole europee, e anche delle scuole in Croazia, in cui la maggior parte degli alunni comincia a studiare una o più lingue straniere dal primo anno della scuola elementare e sviluppa il proprio plurilinguismo prevalentemente tramite l'apprendimento della prima lingua straniera a scuola.

Dal 2003 in Croazia si è sviluppata una nuova prospettiva nell'apprendimento di lingue straniere con l'introduzione di almeno una lingua straniera come materia scolastica obbligatoria nelle elementari, e aggiungendo altre lingue straniere nei cicli successivi. Secondo il Quadro comune europeo (QCER, 2005, 4) l'approccio plurilingue sottintende lo sviluppo della competenza comunicativa comune per tutte le lingue che l'alunno conosce e alla quale contribuiscono il sapere e l'esperienza di tutte le lingue conosciute, ovvero, una competenza in cui s'intersecano tutte quelle lingue. Questo concetto sottintende il collegamento della lingua materna, della prima e seconda lingua straniera, e tutte le altre lingue che l'alunno studia, sia consecutivamente sia parallelamente. Di conseguenza cambia anche l' obiettivo della formazione linguistica, il che non implica solamente l'apprendimento di una, due o tre lingue, separatamente - avvicinandosi così il più possibile al parlante nativo ideale in ciascuna delle lingue -, ma determina, anzi, la creazione di un repertorio linguistico in cui si riflettono tutte le abilità linguistiche. L' obiettivo di questo contributo è di fornire un quadro teorico del plurilinguismo individuale e, analizzando i curricula croati, offrire le linee guida per il suo sviluppo sostenibile con lo scopo di formare utenti plurilingui competenti nelle diverse lingue straniere.

Parole chiave: plurilinguismo individuale, sistema di educazione croato, curricula, lingua madre, lingue straniere 


\section{Plurilingualism in the Context of the Croatian Educational System}

Plurilingualism is primarily defined with regard to the stratification of the verbal repertoire of an individual (Banjavčić, Erdeljac, 2009, 18). According to Königs (2000 in Neuner, 2004, 15) there are three types of plurilingualism: retrospective plurilingualism, relating to bilingual speakers with considerable knowledge of a second language (L2), that is the language being taught, and thus have a substantial advantage in terms of knowledge and skills in this language over the other learners; retrospective-prospective plurilingualism, when learners bring their plurilingualism into the classroom and therefore have a substantial advantage in linguistic knowledge over other learners, but neither of these two languages is the subject being taught, and prospective plurilingualism refers to learners who enter the foreign language classroom as monolinguals and begin developing their plurilingualism in a foreign language classroom. Prospective plurilingualism is typical of the majority of European schools, as well as those in Croatia. When beginning school, most students are faced with learning one or more foreign languages and they extend their plurilingualism by learning their first foreign language in school. A new perspective in the Croatian educational system, with foreign language learning in mind, began with the introduction of at least one foreign language as a compulsory subject in primary schools in 2003, later including even more foreign languages. CEFRL (Common European Framework of Reference for Languages, $2005,4)$ states that the plurilingual approach emphasizes the creation of communicative competence to which all knowledge and experience of language contributes and in which languages interrelate and interact. It certainly entails the interaction between the native language and the first foreign language and other additional languages learned by a student, whether consecutively or simultaneously. Therefore, the aim of language education has changed so that the mastery and acquisition of one or two languages, or even three (resulting in an ideal native speaker) is no longer considered primary, but the creation of a linguistic repertoire in which all linguistic abilities have a place. Furthermore, the offer of foreign languages in educational institutions has to be diversified and at the same time give 
students possibility to develop plurilingual competence. The focus of this work is to provide a theoretical review of plurilingualism and analyze it through Croatian curricula, and provide directions for its sustainable development in forming competent plurilingual users of languages.

Key words: curricula, Croatian educational system, foreign languages, mother tongue, plurilingualism 